\title{
A Protected Minority? Jews and Criminal Justice: Bologna, 1370-1500
}

\section{TREVOR DEAND}

University of Roehampton, London, UK

E-mail:t.dean@roehampton.ac.uk

\begin{abstract}
Though Jews arrived late in Bologna, they soon came to form a considerable community, numbering several hundred by the end of the fourteenth century. The existing historiography of this community is strongly characterized by ideas of inclusion and normalization of Jewish relations with Christian society. In contrast, the historiography of Jews in Renaissance Italy is heavily marked by references to their prosecution for alleged crimes. In exploring this contrast, this article examines fifty Bolognese trials involving Jews between 1370 and 1500, covering homicide, violence, theft, and sexual offenses. In order to reveal the particular character of criminal prosecutions of Jews, they are here placed in a comparative analysis with those of a similar group in the city: students.
\end{abstract}

Keywords Jews $\cdot$ Renaissance $\cdot$ Bologna $\cdot$ Criminal justice $\cdot$ Students

In July 1473 Barnaba Fracassati stole jewels and precious objects, including some silver buttons, from a Jewish pawnshop in Budrio, a small town in the territory of Bologna. ${ }^{1}$ His problems began when he tried to sell some of his loot to a goldsmith in the city. The goldsmith, Master Vitale, inspected a piece of badly melted silver and suspected it might be stolen. Another goldsmith, Francesco, happened to be in his shop and they looked at the silver together. Then Francesco's shop boy reminded them of the burglary: "Master, remember the damage done to the Jew in Budrio." As a result, Vitale refused to buy the silver and handed it back to Barnaba. Later that very day, Francesco had visitors: a group of Jews, relatives of Dattilo, the aggrieved moneylender in Budrio, who asked him if he had seen Barnaba with some silver. Francesco said he had not. But news traveled fast, and the following day, the head of the civic council of Anziani (Elders) sent for Francesco and quizzed him about his knowledge of Barnaba and the silver. Both Dattilo's family and the civic authorities were now on Barnaba's tail. He must have become aware of this, for two days later he came back to Francesco and asked him to accompany him to the church of San Petronio, where, in a side chapel, he confessed to the theft and asked Francesco to protect him and act as his

\footnotetext{
"Pawnshop" is the most usual term in English; Italian more readily uses the simple term banco, or at most banco di prestito su pegno (lit., pawn bank).
} 
intermediary in settling with Dattilo. Francesco agreed but insisted on terms: "I want you to return those things to that Jew, otherwise I shan't mediate between you." Francesco invited Dattilo to Bologna and asked if he wanted to settle with Barnaba and if he was prepared not to divulge that Barnaba was the thief. Dattilo agreed and they arranged a meeting at the church of San Domenico, where Barnaba confessed, expressed his remorse, and offered to restore the goods, consigning to the Dominican prior a quantity of silver and coral, four women's garments, and twelve rings. But Barnaba had already disposed of some other items - garments and rings that he had pawned to Jewish moneylenders in the city - and Dattilo claimed that Barnaba still owed him 200 lire. At this point Francesco left them with the dispute still unresolved. Barnaba eventually undertook to give Dattilo a promissory note, but when he failed to contact Dattilo again, Dattilo went to the judicial authorities and lodged a complaint. ${ }^{2}$

Just a few days later, the authorities in Bologna were investigating another burglary at Dattilo's house, a nocturnal scalamento, or forced entry using ladders. Men on guard at the castle that night were questioned and reported hearing a clamor near Dattilo's house, with shouts of "Who's there?" and people running. One neighbor came out of his house and asked what was going on. "The thieves are in the house of Dattilo the Jew," he heard. The questioning of witnesses led to a suspicion that this burglary was the action of Stefano Fracassati, Barnaba's brother, and he was taken into custody by the podestà. Stefano was not formally prosecuted for this offense-presumably there was insufficient evidence to prove his involvement-but he was ordered, on his release from prison, to provide guarantees that he would not offend Dattilo in the future. ${ }^{3}$

This episode can be used to illustrate one particular interpretation of the position of Jews in fifteenth-century Bologna. Do-it-yourself detection and private settlements with thieves were not unusual, ${ }^{4}$ but in this case it seems that the mediator, Francesco, was more interested in saving Barnaba from the gallows than in assisting the victim, Dattilo: he concealed his knowledge about Barnaba from Dattilo's relatives; he intervened only when Barnaba appealed to him; and he left Dattilo unsatisfied. In Budrio, Dattilo's position became perilous: he suffered two burglaries in a matter of weeks- the second

\footnotetext{
${ }^{2}$ Bologna, Archivio di Stato (hereafter BAS), Curia del Podestà (hereafter Podestà), Vacchettini, busta 10, register (reg.) for Nov. 1472-Oct. 1473, fols. 136r-v (complaint of Dattilo di Elia) and 140r-141r (testimony of Francesco di Antonio).

${ }^{3}$ BAS, Podestà, Vacchettini, 10, reg. for Nov. 1472-Oct. 1473, fols. 160v-161r (Aug. 31, 1473), 203v (Oct. 7, 1473).

${ }^{4}$ Trevor Dean, Crime and Justice in Late Medieval Italy (Cambridge, 2007), 195-97.
} 
suggesting retaliation for his recourse to the authorities - and though neighbors came running at the sound of the scalamento, this was possibly more out of concern for their objects in pawn than for the safety of the moneylender.

This article aims to explore the limits of integration of the small Jewish population in Bologna through a study of policing and judicial records of crimes committed by and against resident and migrant Jews. The experience of Dattilo at Budrio suggests that Christians did not readily assist Jewish residents who had been the victims of crime, and that the judicial authorities did not pursue Jewish complaints with vigor. How representative was this case?

European scholarship on the interaction between Jews and the Christian criminal justice system focuses strongly on discriminatory practices: Lavoie, for example, observes that the courts did not easily acquit Jews of allegations of sexual crimes, subjecting them to prolonged interrogations and torture. ${ }^{5}$ The cases pursued against Jews were sometimes highly unusual, such as that of a midwife accused of causing death in childbirth, and Jews were overrepresented in cases of medical malpractice. ${ }^{6}$ Jews could be brought to trial for offenses committed up to twenty years previously. ${ }^{7}$ Colafemmina has argued that Christians were ever on the alert for faults by Jews that they could denounce. ${ }^{8}$ In this context, scholarship has also stressed a common Jewish reluctance to have recourse to the Christian justice system. In a fatal incident in Rome in 1621 analyzed in depth by Simona Feci, in which a Jew was accused of homicide, the Jewish witnesses were found collectively to distance themselves from the event and to avoid involvement. ${ }^{9}$ Selective memory was also found in Jewish testimony in a blasphemy case against a Jew in Volterra in $1469 .{ }^{10}$ Procaccia has noted strong group solidarity and "not talking" as Jewish strategies of (dis)engagement with courts and judges in pre-ghettoized Rome. $^{11}$

\footnotetext{
${ }^{5}$ Rodrigue Lavoie, "La délinquance sexuelle à Manosque (1240-1430): Schéma générale et singularités juives," Provence historique 37 (1987): 578.

${ }^{6}$ Monica H. Green and Daniel L. Smail, "The Trial of Floreta d'Ays (1403): Jews, Christians and Obstetrics in Later Medieval Marseille," Journal of Medieval History 34 (2008): 186.

${ }^{7}$ Alessandra Veronese, Una famiglia di banchieri ebrei tra il XIV e XVI secoli: I da Volterra (Pisa, 1998), 166-71, 191-92.

${ }^{8}$ Cesare Colafemmina, "The Jews of Reggio Calabria from the End of the XVth Century to the Beginning of the XVIth Century," in Les juifs au regard de l'histoire: Mélanges en honneur de Bernhard Blumenkranz, ed. Gilbert Dahan (Paris, 1985), 258.

${ }^{9}$ Simona Feci, "The Death of a Miller: A Trial Contra Hebreos in Baroque Rome," Jewish History 7 (1993): 15-17, 20.

${ }^{10}$ Veronese, Una famiglia di banchieri ebrei, 193-94.

${ }^{11}$ Micaela Procaccia, "Non dabarà': Gli ebrei di Roma nei primi cinquanta anni del '500 attraverso le fonti giudiziarie,' " in Italia judaica: Gli ebrei nello Stato pontificio fino al Ghetto (1555) (Rome, 1998), 84-87.
} 
In contrast to this emphasis in criminal histories on discrimination and disengagement, the historiography of the Jewish presence in Bologna has emphasized acceptance and integration. In his groundbreaking and still fundamental study, A. I. Pini arrived at a positive conclusion regarding the experience of Jews in this important city of Christian learning in the fourteenth century: the government welcomed immigration for financial, fiscal, and demographic reasons, and integration was easier because Jewish immigrants were well received not only by the government but also by a populace long accustomed, from the presence of the university, "not to distrust foreigners ... and to tolerate diversity." Pini's favorable interpretation has been reinforced in more recent studies by Muzzarelli and Rinaldi focusing on the marriages, businesses, possessions, and wills of specific Jewish families and writing of their success, good repute, established position in the social fabric, and solid relations with Christians and with the civic authorities. ${ }^{12}$ Yet where these studies have used trial records, they have been selective. The purpose of this article is to look more systematically at the judicial evidence in an attempt to reconcile these two contrasting historiographies: one, the history of criminal justice, focusing on discriminatory treatment, and the other, the history of local Jewish business and settlement, stressing integration.

\section{The Historiography of Jewish Criminality}

Before proceeding, two further features of the Jewish presence in Italian cities need to be examined. The first is the nature of Jewish criminality. The historiography in this area has been dominated by examinations of sexual offenses (sex between Jews and Christians being penalized). Baron calculated, from figures earlier put together by Ciardini, that 40 percent of known Jewish crimes in Florence were crimes of sex with Christians. ${ }^{13}$ The only specific example given by Ashtor of documented trials of Jews in fifteenthcentury Venice is a sodomy case ${ }^{14}$ and Mueller points first to cases of alleged

\footnotetext{
12 A. I. Pini, "Famiglie, insediamenti e banchi ebraici a Bologna e nel bolognese nella seconda metà del Trecento," Quaderni storici 54 (1983): 803-4; Maria Giuseppina Muzzarelli, "Ebrei, famiglie e città: Gli Sforno ‘di Bologna,'” Zakhor 3 (1999): 59-77; Rosella Rinaldi, "I Caravita a Bologna: Continuità, dispersioni, frammenti di vita," Zakhor 3 (1999): 95-107.

${ }^{13}$ Salo W. Baron, Ancient and Medieval Jewish History (New Brunswick, NJ, 1972), 245-46; Marino Ciardini, I banchieri ebrei in Firenze nel secolo XV e il Monte di Pietà fondato da Girolamo Savonarola (Borgo San Lorenzo, 1907), 11-12.

${ }^{14}$ Eliyahu Ashtor, "Gli inizi della communità ebraica a Venezia," Rassegna mensile di Israel 44 (1978): 694.
} 
sex with Christian women in illustrating the presence of Jews in Venice before $1508 .{ }^{15}$ Simonsohn found a "disproportionate number of documents" relating to Jews' prohibited sexual relations in Parma in the second half of the fifteenth century, ${ }^{16}$ while in Mantua he identified "pardons" accorded to Jews between 1436 and 1506, four out of five of them for sexual crimes. ${ }^{17}$ Bernardi fills her account of Jews and "papal justice" in the Marca d'Ancona with the prosecution of sex crimes. ${ }^{18}$ Esposito drew attention to the notable sums paid in fines by Jews for sexual relations with Christian women or for sodomy. ${ }^{19}$ Outside Italy in nearby southern France, Lavoie found that Jewish crimes, though rare in thirteenth- and fourteenth-century Manosque, were half composed of rapes and seductions. ${ }^{20}$ Some of these instances would seem to be unthinking reinforcement of stereotypes by historians, while others may reflect the real fiscal and exemplary value for governments of pursuing Jews for alleged sex crimes. The Sforza dukes of Milan used crime as a fiscal resource as a matter of policy, ${ }^{21}$ while the exemplary nature of prosecution - anxiety over Jewish-Christian sexual relations as a proxy for broader antisemitic concerns-is evident in Pope Eugene IV's demand of the death penalty in 1434 for a Jew in Florence convicted of having sexual relations with a Christian prostitute. ${ }^{22}$

Baron's calculation of the proportion of Jewish sex crime in Florence is open to challenge, however, as eighty-five of the documents (half of those he examined) do not state the offense. Moreover, other evidence reduces the scale of sex crime among criminal accusations against Jews. Toaff's survey of evidence in Umbria found just 190 trials of Jews over a period of two

\footnotetext{
${ }^{15}$ Reinhold C. Mueller, "The Jewish Moneylenders of Late Trecento Venice: A Revisitation," Mediterranean Historical Review 10 (1995): 202; and see David Jacoby, "Les Juifs à Venise," in Venezia centro di mediazione fra Oriente e Occidente (secoli XV-XVI): Aspetti e problemi, ed. Hans-Georg Beck, Manoussos Manoussacas, and Agostino Pertusi (Florence, 1977), $1: 170$.

${ }^{16}$ Shlomo Simonsohn, "Alcune note sugli ebrei a Parma nel Quattrocento," in Studi sull'ebraismo italiano in memoria di Cecil Roth, ed. Elio Toaff (Rome, 1974), 235.

${ }^{17}$ Shlomo Simonsohn, History of the Jews in the Duchy of Mantua (Jerusalem, 1977), 204-13.

${ }^{18}$ Simonetta Bernardi, "Gli ebrei e la giustizia pontificia: Alcuni esempi da città della Marca d'Ancona," Rassegna mensile di Israel 67 (2001): 279-84.

${ }^{19}$ Anna Esposito, "Matrimonio, convivenza, divorzio: Rapporti coniugali nella comunità ebraica di Roma tra Quattro e Cinquecento," Zakhor 3 (1999): 121.

${ }^{20}$ Lavoie, "La délinquance sexuelle à Manosque," 576-80.

${ }^{21}$ Franca Leverotti, “'Governare a modo e stillo de' Signori ...': Osservazioni in margine all'amministrazione della giustizia al tempo di Galeazzo Maria Sforza duca di Milano (146676)," Archivio storico italiano 152 (1994): 3-134.

${ }^{22}$ Reinhold C. Mueller, "Lo status degli ebrei nella Terraferma veneta del Quattrocento: Tra politica, religione, cultura ed economia; Saggio introduttiva," in Ebrei nella Terraferma veneta del Quattrocento, ed. Gian Maria Varanini and Reinhold C. Mueller (Florence, 2005), 18.
} 
hundred years (1320-1520). These were unevenly spread, with a concentration in the second half of the fifteenth century, and with a high proportion of crimes associated with the defendants' identities as Jews and moneylenders: 36 percent of trials were for malpractice in lending, fraud, or minor theft, and 11 percent were for actions in contempt of the Christian religion. Apart from these categories, the largest proportions of trials were for violence (28 percent) and gambling (10 percent); the proportions of sexual crimes and homicide were quite low ( 5 percent and 1.5 percent, respectively) ${ }^{23}$ The evidence from Ferrara gathered by Franceschini also shows Jews as more likely to be the victims of violence, robbery, or false accusation ${ }^{24}$ than to practice violence or commit sexual offenses,${ }^{25}$ while the evidence of sentences in Mantua suggests that there was a predominance of cases of theft, assault, and insult. ${ }^{26}$ Equally, Ulbricht's survey of early modern Frankfurt is dominated by property crimes, with other crimes being rare (homicide, serious sexual crimes, crimes against the state). ${ }^{27}$ All of these suggest that the prominence of sexual crimes in the historiography of Jewish criminality needs to be revised.

The second feature of the Jewish presence in Italian cities is Jewish fearfulness of physical attack and judicial maltreatment. The presence of Jews in late medieval Italian cities and towns was based on fixed-term contracts (condotte, capitoli) of between five and ten years negotiated with urban governments. These commonly focused on two themes: regulation of the business of moneylending and assurance of the free exercise of religion, with its implications for separate butchery and burial. The condotte also provided some assurances about the personal safety of Jewish bankers and their families and the security of their belongings. These clauses are less often commented on, but they do manifest anxieties among Jews who were about to settle in a new town regarding their reception by local populations. A common clause (found, for example, in Bolognese condotte) obliged the urban government to compensate Jews in the event of any ransack of their houses by popular

\footnotetext{
${ }^{23}$ Ariel Toaff, Il vino e la carne: Una comunità ebraica nel Medioevo (Bologna, 1989), 134 $39,151-52$.

${ }^{24}$ Adriano Franceschini, Presenza ebraica a Ferrara: Testimonianze archivistiche fino al 1492, ed. P. Ravenna (Florence, 2007), 138, 144, 275-76, 291, 318, 354, 416.

${ }^{25}$ Franceschini, Presenza ebraica a Ferrara, 286-89, 395, 396, 413.

${ }^{26}$ Archivio di Stato Mantua, Archivio Gonzaga, buste 3452-53, fols. 202r, 207r (1432); fols. 432r, 435v, 439r, 441r (1445); fols. 447r, 449v, 460v (1446); fols. 467r, 469r (1447); fol. 504v (1448); fols. 509r, 522v (1449); no foliation (n.f.), Oct. 1456; n.f., Feb. 1457; n.f., Feb. and Oct. 1460; n.f., Jan. and July 1461; n.f., May 1462.

${ }^{27}$ Otto Ulbricht, "Criminality and Punishment of Jews in the Early Modern Period," in In and Out of the Ghetto: Jewish-Gentile Relations in Late Medieval and Early Modern Germany, ed. R. Po-Chia Hsia and Hartmut Lehmann (Cambridge, 1995), 52-55.
} 
rioters or invading soldiers. ${ }^{28}$ In Vicenza in 1435 compensation was offered if Jews were robbed in city or suburbs. ${ }^{29}$ Jews also sought protection against false accusations in the law courts. At Parma it was granted that no "calumny" be accredited by the judges without two trustworthy witnesses. ${ }^{30}$ At Trieste in 1420 , the condotta promised that any accusation or denunciation of any crime except homicide where the penalty was above 100 lire was to be understood as "fictitious, simulated and fraudulent" and that no proceedings were to be taken; and that if any inquiry were made into homicide committed by the banker Salomone, the witnesses were to be tortured. ${ }^{31}$ Similar concerns marked the experience of Jews in more settled communities in the south of Italy. ${ }^{32}$ In moving into new businesses in new places, Jews clearly had fears for their safety: that they might be robbed in public spaces; that their banks and houses might be ransacked; and that the judicial machinery might be used against them, up to and including doubtful charges of homicide.

\section{Jewish Settlement in Bologna}

In Bologna, the first stable Jewish presence seems to date from the 1350s: a member of the Finzi from Rome arrived as part of the late medieval diaspora of Jews from central Italy. Their numbers grew only in the later decades of the fourteenth century: Pini found 131 Jews making transactions requiring a notary between 1350 and 1400, and twenty families in the incomplete tax lists from the 1380s and 1390s (a total of 95 persons), mostly resident in central districts of the city. This group comprised (but was perhaps not limited to) the licensed moneylenders and their families and servants. Making allowances for missing data, Pini estimated a Jewish population of approaching two hundred at the end of the fourteenth century. By that date, there were already also small groups of Jews resident in towns or villages in the contado, and those numbers were to increase subsequently as more contado communities sought authorization to set up pawnshops. ${ }^{33}$ In the fifteenth century,

\footnotetext{
${ }^{28}$ Simonsohn, "Alcune note sugli ebrei a Parma," 231; Veronese, Una famiglia di banchieri ebrei, 269, 272; Franceschini, Presenza ebraica a Ferrara, 62-63; A. Campanini, "Quod possit fenerari: Banchi, prestatori ebrei e comunità rurali del contado bolognese nella seconda metà del XV secolo," in Banchi ebraici a Bologna nel XV secolo, ed. Maria Giuseppina Muzzarelli (Bologna, 1994), 192.

${ }^{29}$ Mariano Nardello, "Il prestito ad usura a Vicenza e la vicenda degli ebrei nei secoli XIV e XV," Odeo olimpico 13-14 (1977-78): 118.

${ }^{30}$ Simonsohn, "Alcune note sugli ebrei a Parma," 249.

${ }^{31}$ Daniela Durissini, "Credito e presenza ebraica a Trieste (XIV-XV secolo)," Zakhor 1 (1997): 73-74.

${ }^{32}$ Cesare Colafemmina, Gli ebrei a Taranto: Fonti documentarie (Bari, 2005), 117-19.

${ }^{33}$ Pini, "Famiglie, insediamenti e banchi ebraici"; Maria Giuseppina Muzzarelli, "I banchieri ebrei e la città," in Muzzarelli, Banchi ebraici a Bologna, 89-157.
} 
the Jewish population further increased, and the number of pawnshops in the city fluctuated, reaching a high of nine in 1406 and a low of four in 143537. Many Jews also passed through the city, mainly lodging in the houses of other Jews. ${ }^{34}$ By 1496 there were thirteen Jewish households, with a total of 162 members, in one quarter of the city alone. ${ }^{35}$

Under the terms of their condotte, Jewish bankers were accorded the rights of citizenship for the duration of their contracts: they were to be treated "as true citizens of the city of Bologna" and were "to enjoy all the privileges that other citizens enjoy." ${ }^{36}$ The issue of Jewish citizenship is much contested. ${ }^{37}$ At one level, it could be argued that there was a difference between being treated as citizens and actually being citizens. Is it significant that no grant of Bolognese citizenship to a Jew has yet come to light? ${ }^{38}$ Giacomo Todeschini has argued that Jews were "only partially citizens," as they were excluded from many of the public and political activities that Christian citizens participated in, such as testifying in court or holding public office, and were treated fiscally as profitable objects, not as contributing subjects. 39 "The recognition of certain Jews as citizens for certain purposes did not mean equality." 40 On the other hand, Roman law jurists accepted that Jews were cives Romani and members of the civic populus, while in late medieval practice some

\footnotetext{
${ }^{34}$ Ermanno Loevinson, "Notizie e dati statistici sugli ebrei entrati a Bologna nel secolo XV," in Annuario di studi ebraici (Rome, 1938), 130, 139-40.

${ }^{35}$ U. Santini, "Cenni statistici sulla popolazione del quartiere di S. Procolo in Bologna nel 1496," Atti e memorie della Deputazione di storia patria per la Romagna, 3rd ser., 24 (1905-6): 342.

${ }^{36}$ Campanini, “Quod possit fenerari,” 199.

${ }^{37}$ Vittore Colorni, Leggi ebraici e leggi locali: Ricerche sull'ambito di applicazione del diritto ebraico in Italia dall'epoca romana al secolo XIX (Milan, 1945), 70-78, 86-94; Ariel Toaff, "Judei cives? Gli ebrei nei catasti di Perugia nel Trecento," Zakhor 4 (2000): 11-12, 26-28; Osvaldo Cavallar and Julius Kirshner, "Jews as Citizens in Medieval and Renaissance Italy: The Case of Isacco da Pisa," Jewish History 25 (2011): 269-318.

${ }^{38}$ None is mentioned in Muzzarelli, "I banchieri ebrei." There is none in the only section of the archive dedicated to grants of citizenship: BAS, Comune, Governo, Cittadinanze (13861511). The grants of citizenship referred to by Loevinson, "Notizie e dati statistici sugli ebrei," turn out to be approvals of requests to reside in the city: 131, 169-72. Among many notarial and financial documents he consulted, Pini found one Jew referred to as civis bononiensis: "Famiglie, insediamenti e banchi ebraici," 799-800. Cf. Jews in Catalan towns, who were not citizens but inhabitants: Christophe Cailleaux, "Les juifs et les musulmans en Catalogne à la fin du Moyen Âge: Des étrangers dans la ville?," in "Arriver en ville": Les migrants en milieu urbain au Moyen Âge, ed. Cédric Quertier, Roxane Chilà, and Nicolas Pluchot (Paris, 2013), 193-210.

${ }^{39}$ Giacomo Todeschini, "Fra stereotipi del tradimento e cristianizzazione incompiuta: Appunti sull'identità degli ebrei d'Italia," Zakhor 6 (2003): 9-20.

${ }^{40}$ Andrew Gow and Gordon Griffiths, "Pope Eugenius IV and Jewish Moneylending in Florence: The Case of Salomone di Bonaventura during the Chancellorship of Leonardo Bruni," Renaissance Quarterly 47 (1994): 292.
} 
documents can be found referring to individual Jews as citizens of specific cities. ${ }^{41}$ More generally, it has recently been argued that "core substantive rights in late medieval Italy" were in any case "defined not by citizenship status" but by the ius comune corpus of laws and norms. ${ }^{42}$

So, Jews had recognized rights and privileges, either as contractors or as citizens under Roman law; yet they themselves harbored fears of discriminatory and violent treatment, and the historiography of crime seems to realize those fears. These contrasts suggest a series of questions that this article will investigate: What can judicial records add to the story of Jewish integration in Bologna? How safe were Bolognese Jews from theft, ransack, and vexatious prosecution? How were Jews treated by the criminal court? Did Jews enjoy the protections of due process afforded to citizens?

\section{Judicial Documentation and Processes in Bologna}

Bologna's rich and extensive judicial archive contains four different types of records of the activities of its criminal courts, presided over by the podestà, his criminal judge, and the capitano del popolo, who were always nonBolognese professionals on short-term contracts. Of those four types, the main source used here is the trial registers, which sequentially document each phase in a trial, from initial denunciation through citation and responses to sentencing. These yield a total of some fifty cases involving Jews between 1370 and 1500 . These cases can be supplemented by other types of records, such as the registers of sentences, the journals of notaries containing witness testimony and interrogations (vacchettini), and the court's "repository papers" (carte di corredo), which consist of papers and parchments submitted to the court in the course of a trial. Additional information comes from the decisions, enactments (provvigioni), and instructions (mandati) issued by the government of the city. The period examined here more or less coincides with the Bolognese "popular state of liberty," inaugurated in 1376 following the city's revolt against its papal overlord and governor. ${ }^{43}$ The following 130 years, down to the recovery of direct papal rule by Pope Julius II, were marked by repeated accommodations with the papacy, repeated revolts, and experiments with both foreign lordship (the Visconti of Milan) and native lordship (the Bentivoglio). The latter, though, were less lords than leaders

\footnotetext{
${ }^{41}$ Colorni, Leggi ebraici e leggi locali, 70-78, 86-94.

${ }^{42}$ Cavallar and Kirshner, "Jews as Citizens," 272-73.

${ }^{43}$ Angela De Benedictis, "Lo 'stato popolare di libertà': Pratica di governo e cultura di governo (1376-1506)," in Storia di Bologna: Bologna nel Medioevo, ed. Ovidio Capitani (Bologna, 2007), 899-950.
} 
of an oligarchy that began to come together institutionally in 1393 with the creation of the executive committee of the Sixteen. The XVI were assigned wide governmental powers, though these did not altogether efface the previous councils of the Anziani, Gonfalonieri, and Massari. A major oligarchical advance occurred in 1450 when the XVI, having been confirmed in office annually since 1447 , were then confirmed indefinitely, the trend being toward life terms and inherited office. ${ }^{44}$

In the Bolognese criminal court, the period from the mid-fourteenth century onward was a very different judicial landscape from that in the late thirteenth and early fourteenth centuries studied by Vallerani and Blanshei. ${ }^{45}$ In the earlier period, accusatory trials predominated, as the standard means of bringing interpersonal violence and property offenses to court. Accusatory trials were marked by very specific forms of initiation, process, and outcome: the injured party initiated the trial, the accuser controlled the process and bore the costs, and the outcome was most frequently a renunciation of the action by the accuser and acquittal of the accused. By contrast, the mid-fourteenth century saw a steep decline in private criminal accusations, ${ }^{46}$ and these became sporadic, a far cry from the hundreds each semester in the late thirteenth century. ${ }^{47}$ What replaced accusation was inquisition, that is, a judicial inquiry undertaken ex officio by a judge, which resulted mainly in condemnations, either in person or in absentia (in cases of contumacy). In addition, inquisition procedure allowed the judge to use torture "to extract the truth" from suspects and witnesses. As one jurist said, "inquisition is more favorable to repressing crime." ${ }^{48}$ Though these two forms are very clearly distinguished in theory by late medieval jurists, modern scholars have pointed to the merging, confusion, or hybridization of forms-whether through the use of a direct complaint (querela) to trigger an inquisition ${ }^{49}$ or through the in-

\footnotetext{
${ }^{44}$ Ian Robertson, Tyranny under the Mantle of St Peter: Pope Paul II and Bologna (Turnhout, 2002), 41-42.

${ }^{45}$ Massimo Vallerani, "L'amminstrazione della giustizia a Bologna in età podestarile," Atti e memorie della Deputazione di storia patria per la Romagna 43 (1992): 291-315; Vallerani, La giustizia pubblica medievale (Bologna, 2005), 124-25; Sarah R. Blanshei, Politics and Justice in Late Medieval Bologna (Leiden, 2010).

${ }^{46}$ Massimo Vallerani, "I processi accusatori a Bologna fra Due e Trecento," Società e storia 78 (1997): 741-88; Sarah Rubin Blanshei, "Criminal Trial Procedures in the Communal and Signorial Eras," in Violence and Justice in Bologna, 1250-1700, ed. Sarah Rubin Blanshei (Lanham, MD, 2018).

${ }^{47}$ Vallerani, La giustizia pubblica, 120.

${ }^{48}$ Angeli de Aretio legum doctoris tractatus de criminibus seu maleficiis (Paris, 1476) [fol. $3 \mathrm{v}]$.

${ }^{49}$ Ibid. [fol. 11r]. On the early history of the querela in Bologna, see Blanshei, Politics and Justice, 441-84.
} 
creasing involvement of defense lawyers ${ }^{50}$ - within a framework of justice as negotiation with the judicial and political authorities, particularly after sentencing, in the form of pleas of poverty and petitions for pardon or cancellation of sentence. The fifteenth century saw the increasing intervention of political authorities - the papal legate, the XVI, the Anziani-in the actions of the criminal court, ${ }^{51}$ as they issued a stream of instructions to the podestà and his judges about which cases to pursue and which to suspend or terminate ("circumvent"), which suspects to torture and what penalties to impose. Much intervention was micropolitical, responding to requests and favors. However, running counter to these trends were two innovations in the power and procedures of the criminal judge. First, from the 1340s the criminal court adopted features of abbreviated trial, summoning the witnesses only if the suspect appeared in court and denied the charge; otherwise the judge proceeded to ban the suspect as contumacious. ${ }^{52}$ Second, the government responded to individual podestàs' pressure for increased powers by authorizing them to inquire "without observing statutory procedures" and by excepting the use of such powers from the judge's mandatory end-of-term review. ${ }^{53}$ With judges on the one hand responding to formal complaints from victims as well as to official denunciations of crimes, while on the other using their powers for summary trials and being subject to interventions by the political authorities, the relation of judges to offenses, conflicts, and political power was a complex one.

So what was the position of Jews in this judicial regime? Jews involved in criminal trials as either suspects, culprits, or victims fall into several status groups. None of the Jews are said to be citizens, but this was customary for public documents. ${ }^{54}$ Most of them are described as "residents" (habitatores) of the city ${ }^{55}$ or are located by parish, implying residence. A smaller number are specifically designated as "foreigners" (forenses) and a few as

\footnotetext{
${ }^{50}$ Dean, Crime and Justice in Late Medieval Italy, 26; So Nakaya, "La giustizia civile a Lucca nella prima metà del XIV secolo," Archivio storico italiano 169 (2011): 657-68.

${ }^{51}$ Trevor Dean, "Criminal Justice in Mid-Fifteenth-Century Bologna," in Crime, Society and the Law in Renaissance Italy, ed. Trevor Dean and K. J. P. Lowe (Cambridge, 1994), 26, 34-35.

${ }^{52}$ Trevor Dean, "Crime and Plague: Bologna 1348-51," Continuity and Change 30 (2015): 17.

${ }^{53}$ Dean, "Criminal Justice in Mid-Fifteenth-Century Bologna," 30. Cf. the different origin and scope of such powers in the early fourteenth century discussed in Blanshei, Politics and Justice, 441-84.

${ }^{54}$ Cavallar and Kirshner, "Jews as Citizens," 273.

${ }^{55}$ On this term, see Renata Segre, "Flussi e correnti migratorie nel mondo ebraico: Fonti e storiografia," in La storia degli ebrei nell'Italia medievale: Tra filologia e metodologia, ed. Maria Giuseppina Muzzarelli and Giacomo Todeschini (Bologna, 1989), 81-82.
} 
"vagabonds," a term with negative connotations by this period. ${ }^{56}$ The residents involved in trials did include some Jews who ran or participated in banks in the city and its territory (contado), such as Guglielmo di Dattilo, victim of a brawl in 1383; Salomone di Matasia da Perugia, victim of a nocturnal assault in the street in 1396; Aleuccio di Gaglio, a victim of public insult in 1399; Abramo di Dattilo, twice arraigned on sex charges; Liuccio di Angelo da Ferrara, corporally punished and exiled for theft in 1422; and Manuele di Musetto da Modena, accused but acquitted of theft in $1475 .^{57}$ The more serious crimes tended to be committed by vagabonds: Manuele from Germany was condemned for robbing and killing a Florentine in 1417; another German, Salomone, confessed to numerous thefts over a period of years from Jews' houses and the Jewish hostel in Bologna ${ }^{58}$ Foreign Jews, designated as "from" Padua, Poland, Rome, and so on, perhaps just passing through Bologna, confessed variously to stealing from a church, a bank, or a house; to wounding with bloodshed; and to sex in the brothel. ${ }^{59}$ As suspected or condemned perpetrators of crime, resident Jews do not appear before 1390, when Abram di Bonaventura da Rimini confessed to having sex with Christian women. Thereafter resident Jews appear in trials for brawling $(1408,1418,1422,1424,1465)$, assault $(1412,1453,1478,1479,1482)$, theft $(1412,1475,1479)$, blaspheming and assisting a criminal (1413), sexual crimes $(1422,1426,1432,1433,1456)$, and counterfeiting (1473). Performing a particular role-never as suspects-were members of the Sforno family, wealthy and well connected moneylenders. Rubino di Samuele Sforno attested to the good repute of a young Jewish boy who had confessed to sodomy and helped secure his acquittal. ${ }^{60}$ Later in the century, Rubino's son Abramo appears in the court documents twice as a victim of theft (by other

\footnotetext{
${ }^{56}$ Giuliano Pinto, "Popolazione e comportamenti demografici in Italia (1250-1348)," in Europe en los umbrales de la crisis: 1250-1350 (Pamplona, 1995), 55.

${ }^{57}$ BAS, Podestà, Inquisitiones, 241, reg. 5, fol. 144r (1383); ibid., 270, reg. 2, fols. 107rv (1396); ibid., 276, reg. 1, fol. 34r (1399); ibid., 340, reg. 4, fol. 64r (1432); ibid., 377, fols. 117r-118r (1475); BAS, Capitano del popolo, Giudici, reg. 862, fols. 17r-18r (1422); BAS, Podestà, Sententiae, 37 (Sept. 1422). For the involvement of Jews in lending banks, see Rosella Rinaldi, "Topografia documentaria per la storia della comunità ebraica bolognese," in Muzzarelli, Banchi ebraici a Bologna, 76; Muzzarelli, "I banchieri ebrei," 96, 98, 105, 109, 138.

${ }^{58}$ BAS, Podestà, Inquisitiones, 307, reg. 1, fol. 98r (1417); ibid., 347, reg. 1, fols. 41r-42r (1440).

${ }^{59}$ BAS, Podestà, Inquisitiones, 217, reg. 4, fol. 16r (1373); ibid., 230, reg. 4, fol. 48r (1378); ibid., 386, reg. 1, fols. 273r-274r, 276r (1485); ibid., 318, fols. 153r-155r (1423); BAS, Podestà, Sententiae, 30, fols. 46v-47r (1399).

${ }^{60}$ BAS, Podestà, Inquisitiones, 336, reg. 2, fols. 44r-48v (1433). On Rubino di Samuele, see Muzzarelli, "I banchieri ebrei," 110.
} 
Jews) and once as a witness to the wounding of a Jewish resident. ${ }^{61}$ Abramo's brother Salomone also claimed to be a victim of theft in 1464, as described above. Beyond those who were engaged in moneylending, few other occupations are recorded: a Jewish tailor, resident in Bologna, was assaulted in 1406; two French cloth traders, "former residents of Bologna," were convicted of rape and sodomy in $1437 .{ }^{62}$ Jewish women appear rarely, and only as victims-mostly of sexual coercion, ${ }^{63}$ once of murder. ${ }^{64}$

The question thus arises how far the Jews who appear in the criminal court were representative of the broader Jewish community living in Bologna. Most were indeed residents in the city; the foreigners and vagabonds were a minority. Those engaged in moneylending did figure in trials: as victims in the later fourteenth century, as suspects and culprits as well in the fifteenth. Some other trades are recorded, but few or no medics (a "maestro" was victim of an alleged assault in 1462, the servants of a medic in another in 1447). ${ }^{65}$ Members of more settled and connected families, such as the Sforno, appear only as victims and witnesses, women only as victims. The Jews on trial thus formed a particular group within the Jewish community, but one not so far removed from the segment of the population represented in fifteenth-century trials of Bolognese society more generally, in which elite families rarely appeared as suspects, and in which trials of women (mainly for specific petty crimes) were a tiny proportion.

\section{Trial Procedures}

A key issue in exploring the limits of integration through judicial records is the court's adherence to criminal trial procedures. There is little in the trials to suggest that Jews were denied due process. Like other city dwellers, they had access to the local officials who could denounce crimes at their "instigation and request," as when a Hungarian living in Bologna was charged with assaulting Leuccio di Gaio in the street, ${ }^{66}$ although the fact that most cases

\footnotetext{
${ }^{61}$ BAS, Podestà, Inquisitiones, 380, fols. 122r-124r, 143r-147r (Dec. 1479); BAS, Podestà, Vacchettini, 18, reg. for Jan.-June 1493, fol. 35r. On Abramo di Samuele, see Muzzarelli, "I banchieri ebrei," 116, 144.

${ }^{62}$ BAS, Podestà, Inquisitiones, 287, reg. 3, fol. 104r (1406); ibid., 341, reg. 1, fol. 75r (1437).

${ }^{63}$ BAS, Podestà, Inquisitiones, 304, reg. 2, fol. 27r (1416); ibid., 341, reg. 1, fol. 75r (1437); BAS, Podestà, Sententiae, 38, fol. 47v (1426).

${ }^{64}$ BAS, Comune, Governo, Liber Fantini, fol. 44r (Mar. 14, 1437).

${ }^{65}$ BAS, Podestà, Vacchettini, 7, reg. for Apr.-May 1462, fol. 13r; BAS, Carte di corredo, 265 , Aug. 7, 1447. Jewish medics appear to be poorly documented in Bologna: Stefano Arieti, "Medici ebrei a Bologna tra XV e XVI secolo," in Verso l'epilogo di una convivenza: Gli ebrei a Bologna nel XVI secolo, ed. Maria Giuseppina Muzzarelli (Florence, 1996), 235-43.

${ }^{66}$ BAS, Podestà, Inquisitiones, 276, reg. 1, fol. 34r (1399). For another example of a Jew using the querela procedure, see ibid., 379, reg. 1, fols. 171r-177r (1478).
} 
against Jews started as inquisitions rather than denunciations, when the general pattern was the reverse, suggests that there was no zeal among the local officials to report perceived Jewish offenses ${ }^{67}$ If Jews appeared in court to respond to the charges, they were, as was the practice with other suspects, either bailed or, if they lacked guarantors, held in custody. As with other suspects too, procurators could appear on their behalf to enter objections to the charges against them, as in the case of Vidaluccio di Daniele, denounced for wounding a notary's son with a stone: the objection was that Vidaluccio was a child, and two other Jews attested that he was under twelve, as he had not yet "said the office ... as is Jewish custom and law"; 68 and consequently, the judge terminated the trial. Equally, the possibility was open to Jews, as to Christians, of confessing and paying an amount into the communal treasury before sentencing, as a way of avoiding conviction. ${ }^{69}$ They were also able, if they had confessed their crime, to present a "deed of pacification" with their victim and enjoy a reduction of sentence, as in the case of a brawl between two Jews in the village of Oliveto. ${ }^{70}$ Nor was gracious pardon foreclosed to Jewish supplicants, even for serious sexual crimes (see below). From initiation to termination of trials, the court thus seems to have followed the same process for Jewish suspects as for Christians.

Nevertheless, there were some specific features in trials of Jews that are suggestive of different treatment. First, the relative scarcity of denunciations of crimes when Jews were the victims suggests a degree of reticence on the part of local officials, a choice not to cooperate with justice. ${ }^{71}$ Second, the prosecutorial rhetoric was occasionally ratcheted up with reference to "contempt of the Christian faith," evident not only in the case of a foreign Jew such as Musetto from Camerino, who stole objects from the altar of a church in Castelfranco, ${ }^{72}$ but also in that of a Bolognese resident, Salomone da Pesaro,

\footnotetext{
${ }^{67}$ For the balance between inquisitions and denunciations in the second half of the fifteenth century, see Sara Cucini, "Léglislation statutaire et gouvernement pontifical en Italie centrale: Le cas de l'administration de la justice criminelle à Bologne, deuxième moitié du XV siècle" (PhD diss., Université Montpellier 3 and Università di Bologna, 2014), 337-40.

${ }^{68}$ BAS, Podestà, Inquisitiones, 314, reg. 1, fols. 27r-29v (1421).

${ }^{69}$ Thus Isaac di Manuele from Poland ("de partibus Apolonie") used this method to avoid conviction on a charge of having sex with prostitutes (BAS, Podestà, Inquisitiones, 386, reg. 1, fol. 273r [1485]), as did Leuccio da Pesaro in connection with charges related to a blasphemous brawl at a fishmonger's stall (ibid., 320, fol. 47r [1424]). On this procedure, see Dean, "Criminal Justice in Mid-Fifteenth-Century Bologna," 28.

${ }^{70}$ BAS, Podestà, Inquisitiones, 308, reg. 1, fol. 16r (1418). Likewise: BAS, Capitano del popolo, Giudici, reg. 854, fol. 11r (1412). Cf. James A. Palmer, "Piety and Social Distinction in Late Medieval Roman Peacemaking," Speculum 89 (2014): 991.

${ }^{71}$ Martine Charageat and Mathieu Soula, "Introduction: Ce que dénoncer veut dire," in Dénoncer le crime du Moyen Âge au XIXe siècle, ed. Martine Charageat and Mathieu Soula (Pessau, 2014), 11.

${ }^{72}$ BAS, Podestà, Inquisitiones, 217, reg. 4, fol. 16r (1373): Musetto "de Cambarino."
} 
who was prosecuted for having sex with Christian prostitutes. ${ }^{73}$ Third, the particular plight of Jews arrested for serious crime is illustrated in the case of Manuele di Beniamino da Rimini and Elia di Salomone, charged with committing sodomy when they slept in the same bed in October $1432 .{ }^{74}$ Both of them confessed. Elia, between the date of the offense and the date of the trial, converted to Christianity, as did some other Jews when held in prison: in an environment that posed particular risks of new and unwitting offenses and blasphemies, ${ }^{75}$ Jews were understandably drawn to conversion by the prospect of a reprieve. ${ }^{76}$ Manuele, conversely, chose the path of contesting the charge and denying that his confession was valid, as he had made it out of fear of torture. Claiming to be a "young and timorous adolescent," he said he had been persuaded to confess by the court officials, as the alternative was torture. One of the witnesses he called in support was a nobleman, Galeotto Canetoli, who had just returned from Rome where he had been negotiating with the pope on behalf of the city; ${ }^{77}$ Galeotto said that he had sent for Rubino di Samuele (Sforno) to persuade Manuele to confess and had offered to get Manuele a pardon if he did. What is going on in this case is unclear: why would a leading member of the elite try to persuade a young Jew to confess to a crime that carried a death sentence, while also promising a pardon? What it may demonstrate is that Jews in jail constituted a resource or opportunity for Christian authorities: they could be pressured to convert, and they could be drawn into noble clientage relations through the operation of favors. Another unusual feature of this case was the delayed trial: there were statutory time limits for the start of criminal proceedings-usually one to two months depending on the location of the crime ${ }^{78}$ - yet Manuele's trial opened nine months after the alleged offense. An even longer delay occurred when another Jew was prosecuted for adultery in March 1436, although the actions had allegedly taken place in early $1432 .{ }^{79}$

\footnotetext{
${ }^{73}$ BAS, Podestà, Inquisitiones, 323, reg. 2, fol. 133r (1426).

${ }^{74}$ BAS, Podestà, Inquisitiones, 336, reg. 2, fols. 44r-48r (1433).

${ }^{75}$ Stephen Bowd, "Civic Piety and Patriotism: Patrician Humanists and Jews in Venice and Its Empire," Renaissance Quarterly 69 (2016): 1271.

${ }^{76}$ BAS, Podestà, Inquisitiones, 373, fol. 294v (1473); ibid., 347, reg. 1, fol. 41r (1440). For a case in 1420 involving the bishop, see Paolo De Töth, Il beato Nicolò Albergati e i suoi tempi, 1373-1444 (Acquapendente, 1922), 1:273. More generally, see Reva Berman Brown and Sean McCartney, "Living in Limbo: The Experience of Jewish Converts in Medieval England," in Christianizing Peoples and Converting Individuals, ed. Guyda Armstrong and Ian N. Wood (Turnhout, 2000), 178.

${ }^{77}$ Gianfranco Pasquali, "Canetoli, Galeotto," in Dizionario biografico degli italiani (Rome, 1975), 18:35-37.

${ }^{78}$ BAS, Statuti, 16 (1454), fol. $4 \mathrm{r}$.

${ }^{79}$ BAS, Podestà, Inquisitiones, 340, reg. 4, fols. 64r-65r (1436).
} 
Torture presented further potential for exploitative treatment. The prosecution of Manuele is the only trial record of a Jew to mention torture. This silence is quite usual in all trials, as the judicial record presents the results of investigation, not the process of investigation itself. It is the court notary's journals (vacchettini), which survive only from the mid-fifteenth century, that record investigations, and these show that Jews were occasionally tortured, sometimes within and sometimes outside the regulations. Enoch di Salomone da Ferrara was tortured only after his denials of involvement in a counterfeiting gang were directly belied by another gang member: vacillation constituted legitimate grounds for torture, ${ }^{80}$ and the common opinion among jurists was that in concealed crimes such as counterfeiting the judge should be "easier and readier to torture." ${ }^{81}$ Conversely, Consiglio di Musetto, a resident of Bologna, had already confessed to the charge against him, of having sex with a Christian prostitute, but was tortured to "tell the truth" about previous offenses. ${ }^{82}$ This sort of speculative questioning without specific incriminating evidence was not sanctioned by treatises on torture. ${ }^{83}$ As a practice, it was usually applied to suspected thieves. ${ }^{84}$ Moreover, there is evidence that some Jewish suspects were treated differently, as in a case from 1467 when one of the podestà's own officials confessed to extracting money from a resident Jew, detained for alleged adultery, in return for supporting him physically during torture in order to reduce the pain: a unique example of such official misconduct and another way in which Jewish prisoners could be seen as objects to be exploited. ${ }^{85}$

\section{Integration: The View from Judicial Sources}

\section{Uneven Distribution across Time}

The judicial records also suggest that any social integration evolved over the period. The fifty trials involving Jews are not evenly distributed across time. Over half of them fall in the years from 1372 to 1424 , and most of those

\footnotetext{
${ }^{80}$ BAS, Podestà, Vacchettini, 10, reg. for Nov. 1472-Oct. 1473 (June 13, 1473).

81 "Facilior et promptior." Tractatus de indiciis et tortura D. Francisci Bruni de S. Severino ... D. Guidonis de Suzaria ... et D. Baldi de Periglis ... cum additionibus D. Ludovici Bolognini (Venice, 1549), fol. 73v.

${ }^{82}$ BAS, Podestà, Vacchettini, 5, reg. for Jan.-June 1456 (June 25, 1456).

${ }^{83}$ Tractatus de indiciis et tortura, fols. $76 \mathrm{v}-77 \mathrm{r}$.

${ }^{84}$ Stefano Piasentini, “Alla luce della luna”: I furti a Venezia, 1270-1403 (Venice, 1992), 34-35.

${ }^{85}$ BAS, Podestà, Vacchettini, 8 , reg. for Dec. $1467-$ May 1468, fols. 6r-8r. The suspect is variously recorded as "Angelus Ysac Venture" and "Angelus Manuelis Venture."
} 
(twenty-two out of thirty-two) took place during the period from 1400 to 1424. After 1425, the cases settle to a consistent rate of between six and eight every twenty-five years. It is unlikely that these constituted all the trials involving Jews across this period, as some documentation is clearly missing. The trial records particularly after 1445 have numerous lacunae, either within registers (missing folios) or between registers (missing months and years); the registers from the first half of the century make up seventy-seven archival buste, whereas those from the second half make up only forty-three. Moreover, other sources, such as the vacchettini, refer to cases that are not found in the extant trial registers. The distribution of the types of cases does, however, suggest an interpretation linking the trials to contextual political and religious factors. In the later fourteenth and first years of the fifteenth centuries, most of the trials involving Jews concern assaults on Jews in the streets, as if the court were serving a protective function. In two of these cases the alleged perpetrators were clerics. ${ }^{86}$ A clergyman also seems to have played a role in instigating the first recorded ransack of a Jew's house in the rural village of Massa Lombarda in 1395: seven men were prosecuted for murdering Godio di Vitale, resident there, and for engineering a riot in which his house was ransacked. Godio was ambushed in the street, cut so badly that his body was left "in pieces," and a riot was incited with the shout, "Long live the commune of Bologna! Everyone to Godio's house for the stuff!" 87 The chronicle of Matteo Griffoni briefly noted this event: four men were hanged, he records, five banished, and many others fled. He identified the local priest as the cause of this violent outburst.

\section{The Rise and Fall of Vexatious Prosecution}

This protection was replaced in the early fifteenth century by clear cases of vexatious use of the criminal court. In 1414 there was a troubling conspiracy to eliminate some Jews in the city, a calumny in which a group of Jewish bankers was falsely accused of stealing a crucifix from a church and then burning it during the festival of Purim; the real criminals were a Jew, a converted Jew, and a Christian who had invented the calumny and who were all condemned to death by hanging. ${ }^{88}$ A climate conducive to accusations against Jews was then maintained by Bishop Nicolò Albergati, elected in 1417 , who ordered Jews to wear a distinguishing sign, intervened to reduce the interest rates they charged, and brought San Bernardino of Siena to

\footnotetext{
${ }^{86}$ BAS, Podestà, Inquisitiones, 215, reg. 6, fol. 75r (1372); ibid., 241, reg. 5, fol. 144r (1383).

87 "Viva viva il comune di Bologna omni huomo vada accasa di Ghodio per la robba." BAS, Carte di corredo, 174, Feb. 22, 1395. The indictment states that goods worth 800 ducats were plundered.

${ }^{88}$ Rinaldi, “Topografia documentaria," 75-79.
} 
Bologna in 1423-24 to preach, among other things, against usury. ${ }^{89}$ Correspondingly, between 1417 and 1435 all the prosecutions but one were against Jews, for crimes ranging from homicide, assault, and brawling to burglary, theft, sodomy, and sex with Christian women.

As the Bentivoglio consolidated their power, however, expelling their rivals the Canetoli in 1445, trials involving Jews became rarer. It may not be coincidental that there were solid relations between the Bentivoglio and Jewish bankers, the Bentivoglio having been assigned by the XVI the proceeds of the tax on Jewish banks, which brought them perhaps one thousand lire each year. ${ }^{90}$ A more lenient attitude toward the wearing of the sign is also evident in this period: when a group of Jews was arrested in February 1469 for failing to wear "the sign in common parlance called 'the $\mathrm{O}$," " as required by a papal decree, an ordinance of the papal governor, and a provision of the Bolognese government, they objected that only the governor's ordinance was "in continued observance," that the papal decree and communal provision were not, and that they had not contravened the governor's decree. The podestà accepted their argument. ${ }^{91}$ When a blood libel surfaced in Bolognese territory in 1492 — an allegation of buying Christian blood — the Jewish suspects stoutly defended their innocence and were acquitted. ${ }^{92}$ Moreover, it was Giovanni Bentivoglio who was indirectly responsible for the failure of the Bolognese Monte di pietà when it was established in April 1473: denied adequate funding, it closed after eighteen months. ${ }^{93}$ The campaign to establish municipal pawnshops, aimed at reducing the cost of credit for the poor, had been championed by the Observant Franciscan friars in an explicitly antisemitic manner. At the same time as it established a monte in Bologna, the government of the XVI also directly attacked the business model of the Jewish pawnshops by insisting that Jewish bankers should not retain the full proceeds of the sale of unredeemed pawns, but should pay to the owners the difference between the value of the loan and the sale price. ${ }^{94}$ This economic attack on Jewish pawnshops, inspired by Observant preaching, may plausibly be connected to a rise in the number of cases of thieving from Jewish banks

\footnotetext{
${ }^{89}$ De Töth, Il beato Nicolò Albergati, 1:257-58, 267-73.

${ }^{90}$ Massimo Fornasari, Il "thesoro" della città: Il Monte di Pietà e l'economia bolognese nei secoli XV e XVI (Bologna, 1993), 36-37.

${ }^{91}$ BAS, Podestà, Vacchettini, 8, reg. for Dec. 1468-Mar. 1469 (Feb. 27-28, 1469). The papal decree was that of Nicholas V, on which see Filippo Sedda, "Giovanni da Capestrano esecutore generale contro gli ebrei: La lettera Super gregem dominicum di Niccolò V (1447)," Studi francescani 110 (2013): 297-325. The governor's decree was that of Luis Juan del Milà, legate in Bologna from 1455, on which see Muzzarelli, "I banchieri ebrei," 124.

${ }^{92}$ Rinaldi, “Topografia documentaria," 84-87.

${ }^{93}$ Fornasari, Il "thesoro" della città, 56-61.

${ }^{94}$ Fornasari, Il "thesoro" della città, 42-43.
} 
and houses in Bologna and its territory: the first in a sequence occurring in August 1473, as narrated above.

\section{The Distribution, Character, and Narration of Crimes involving Jews}

The distribution, character, and narration of crimes involving Jews could reflect their level of integration. How did the prosecution of Jews compare numerically to that of the Christian population? Comprehensive figures for all trials in Bologna across the whole period have not yet been produced, but some samples from the 1370s, 1410s, and 1430s suggest that trials for assault usually constituted around 60 percent of the total, homicide between 10 and 20 percent, theft between 5 and 15 percent, and sexual crimes around 3 percent, with a variety of other offenses completing the total. A recent sample of fourteen years of trials between 1447 and 1511 found that 67 percent constituted crimes of violence (including homicide) and 12 percent theft, with sexual and other crimes accounting for the remainder. ${ }^{95}$ Bolognese trials involving Jews broadly followed this pattern. The most commonly prosecuted crimes with Jews as either perpetrators (alleged or convicted) or victims were violence and theft, with a small group of sexual offenses. Homicides and assaults were the more typical and more serious. There were only two trials of Jewish killers (both were banned): in one, a vagabond Jew from Germany killed and robbed a Florentine man in 1417; in the other, Dattolino di Musetto, resident at Castel San Pietro, stabbed a man to death one night in $1482 .{ }^{96}$ There are references to other such crimes, however: a Jewish "robber and killer" was arrested in 1447; and in 1460 eyewitness testimony was gathered from those who had seen Moyses stab Simone di Manuele, a resident at Varignana, in the head with a knife, a wound from which Simone was said to have died. ${ }^{97}$ There was nothing out of the ordinary about these murders, which show Jews conforming to general modes of homicide: a small number of wounds with common weapons such as a knife or a spear.

Where Jews were victims, it was a different story. The frenzied killing of Godio at Massa Lombarda in 1395 has already been mentioned. The following year in the city, Salomone di Matassia da Perugia was chased through the city streets at night by an assailant who threw stones to separate him from his fellow Jews; when Salomone hid, his pursuer killed his servant Guglielmo di Datelusso da Perugia with one sword blow to the head. ${ }^{98}$ In an incident in

\footnotetext{
${ }^{95}$ Cucini, "Léglislation statutaire et gouvernement pontifical," 334-50.

${ }^{96}$ BAS, Podestà, Inquisitiones, 307, reg. 1, fol. 98r; ibid., 383, fol. 302r.

${ }^{97}$ BAS, Podestà, Vacchettini, 6, reg. for July-Dec. 1460 (Aug. 14, 1460); BAS, Comune, Governo, 396, Libri mandatarum, reg. 9b, fol. 17v (1447).

${ }^{98}$ BAS, Podestà, Inquisitiones, 270, reg. 2, fols. 107r-v (1396).
} 
1428, a nine-year-old boy threw a stone against a Jew's house, and it accidentally ricocheted from a column, fatally striking a Jewish woman sitting in the portico. ${ }^{99}$ In 1443 Niccolò di Giorgio da Pieve, with two armed accomplices, assaulted Manuele di Sabato da Montagnana in the castle at Pieve, inflicting many wounds and causing his immediate death. ${ }^{100}$ During a robbery at the house of Zanatan di Emanuele in 1474, during which goods and merchandise were stolen, Zanatan was killed. ${ }^{101}$ These killings are marked by irregular features. First, the murderous attack on Salomone was said to be motivated by hatred, an uncommon detail in Bolognese trial records, which more normally and formulaically ascribe violence to anger. Second, throwing stones at Jews' houses was a widespread and common practice, one that was received as antisemitic by its victims; ${ }^{102}$ it was not limited to the ritualistic sassaiole in Christian holy week, described as "much noise ... little damage ... the next day normal life resumed." 103 Third, the killers of Manuele di Sabato were acquitted on a technicality because of a wartime enactment of 1444 excusing crimes that had been committed against soldiers "and other foreigners" in Bolognese territory in mid-1443: it looks as if the meaning and intention of this enactment were stretched to allow the killing of a Jew to be covered by it.

Assaults against Jews also showed asymmetries. Jews were victims more often than assailants (by two to one), and when they were victims, their assailants were Christians more often than other Jews (also by two to one). These figures can obviously be read in two ways: on the one hand, the court did hear and prosecute injuries to Jews; on the other, Jewish relations with Christians were marked by violence in which Jews were most often the victims. Qualitatively, however, the assaults by Jews did have unusual features: they were often unarmed affairs of punches to the face and nose, ${ }^{104}$ and in other cases they involved merely the aggressive, threatening use of weapons. ${ }^{105}$ At most, Jews caused injuries with sticks or stones, thrown or

\footnotetext{
${ }^{99}$ BAS, Comune, Governo, Liber Fantini, fol. 44 (Mar. 14, 1437): response to a petition to confirm acquittal, as the original sentencing document could not be found.

${ }^{100}$ BAS, Capitano del popolo, Giudici, reg. 868, fols. 7r-9r (1445).

${ }^{101}$ BAS, Comune, Governo, 325, Riformagioni e provvigioni, Serie miscellanea, reg. 12, Dec. $29,1473$.

${ }^{102}$ At Crema, the capitoli with Jews in 1449 provided for fines for throwing stones or earth at Jews: Giuliana Albini Mantovani, "La communità ebraica in Crema nel secolo XV e le origini del Monte di Pietà," Nuova rivista storica 59 (1975): 385.

${ }^{103}$ Toaff, Il vino e la carne, 219-21; Kenneth R. Stow, Alienated Minority: The Jews of Medieval Latin Europe (Cambridge, MA, 1992), 240.

${ }^{104}$ BAS, Podestà, Inquisitiones, 287, reg. 3, fol.104r (1406); ibid., 291, reg. 2, fol. 91r (1408); ibid., 296, reg. 1, fols. 52r-53v (1411); ibid., 310, reg. 2, fols. 63r-66r (1419).

${ }^{105}$ BAS, Podestà, Inquisitiones, 308 reg. 1, fol. 16r (1418).
} 
wielded. ${ }^{106}$ Though Jews would have had access to domestic knives, they had little access to the more militarized weaponry increasingly found in trials of assault and homicide in the fifteenth century. Only rarely were they fined on the streets by officials for carrying weapons. ${ }^{107}$ Surprisingly, assaults against Jews rarely used these weapons, either. ${ }^{108}$ Where most intra-Christian violence resulted in bloody, but not fatal, wounds caused by knives, swords, lances, or tools, this sort of injury is almost completely absent in nonfatal assaults on Jews. Even more surprisingly, given the tensions that arose from alleged Jewish malpractices in accepting and releasing pawned goods, ${ }^{109}$ only one Christian assault on a Jew seems even possibly related to moneylending activity: a case in which a porter went to the house of a Jew and, after insulting him, threw a pot of ink in his face, soiling him and his business registers. ${ }^{110}$

\section{Attitudes toward Jews}

What judicial sources can reveal about attitudes toward Jews in public spaces has implications for their integration. Some assaults on Jews seem to be part of a contestation of the use of space and facilities. Jewish presence on the streets at certain times could be seen as a provocation by Christians, as for example when Jewish funeral corteges were attacked and dispersed (Perugia 1446, Piacenza 1470). ${ }^{111}$ When a man tipped a pot of dung over the shoulders of "maestro" Leone in the street in 1462, a female witness commended the assailant on his deed. ${ }^{12}$ One night in 1406 two Bolognese men seized Daniele di Jacobo while he was walking along a street, extinguished and

\footnotetext{
${ }^{106}$ BAS, Podestà, Inquisitiones, 314, reg. 1, fol. 27r-29v (1421); ibid., 318, fols. 153r-155r (1423); ibid., 379, reg. 1, fols. 171r-177r (1478); ibid., 380, fol. 101r (1479).

${ }^{107}$ The only possible case I have found so far, to judge from the miscreant's name, is in BAS, Podestà, Vacchettini, 4, reg. for 1426-27 (Jan. 8, 1427: Lione di Elia da Perugia imprisoned for carrying a large knife).

${ }^{108}$ The sole known example of a prosecuted assault by a Christian on a Jew involving a dagger is in Inquisitiones, 246, reg. 6, fol. 80 (1385). But the charge was denied and the testimony was insufficient for conviction.

${ }^{109}$ See, e.g., Shlomo Simonsohn, ed., The Jews in the Duchy of Milan (Jerusalem, 1982), 1:508, 511. Cf. Julie Claustre, "La dette, la haine et la force: Les débuts de la prison pour dette à la fin du Moyen Âge," Revue historique 309 (2007): 797-820.

${ }^{110}$ BAS, Comune, Governo, 385, Libri partitorum, reg. 5, fol. 52v (1463).

${ }^{111}$ Toaff, Il vino e la carne, 67-68; Carmen Artocchini, "Presenze ebraiche a Piacenza nell'alto e basso Medioevo," Archivio storico per le province parmensi, 4th ser., 44 (1992): 117-18; Simonsohn, Jews in the Duchy of Milan, 506, 508.

${ }^{112}$ BAS, Podestà, Vacchettini, 7, reg. for Apr.-May 1462, fol. 13r.
} 
broke his torch, and did not let him pass; this was the sort of obstructive behavior that citizens might inflict on peasants, or peasants on slaves. ${ }^{113}$ Similar events are recorded later in the century. In 1463, the podestà was ordered to proceed against Folco de' Gigli for seizing an object from a Jew's head. ${ }^{114}$ In 1480 on successive Saturday nights a Jewish man was manhandled in the street by armed assailants who seized his torch and tried to grab his cloak and turcha. ${ }^{115}$ In 1498 a Portuguese Jew was returning home early one Saturday evening, and (he alleged from his convalescent bed) as he passed the brothel five women seized the hat from his head and ran with it into the brothel, pulling him with them as he tried to retrieve it. Once inside they tried to bully him to show them "his member," before a man came up and struck him about the head and shoulders with a stick. ${ }^{116}$

\section{Were Jewish Banks a Target?}

A further insight relates to the attitudes toward Jewish pawnshops. Jewish houses and business premises could be seen as obvious targets for theft, filled as they were with clients' pawns, ${ }^{117}$ and the ransack of the Jew's house at Massa Lombarda was not the only example of its kind. ${ }^{118}$ When appealing for information in 1503 on the burning and plundering of the bank of Manuele in the Strada Maggiore, an edict described the following list of stolen property: garments of wool or silk, jerkins, cloaks, hoods, beds, bolsters, bed coverings, sheets, tablecloths, benches, spalliere, carpets, books, rings, belts, coins, basins, candlesticks, weapons, plates, bowls, and countless other household objects of copper, pewter, and iron. ${ }^{119}$ A similar collection of over one hundred items of clothing and household objects was stolen from the house of Musetto on the Strada San Donato in September 1456, and two Christian inhabitants were prosecuted and sentenced to hang. ${ }^{120}$ Christian thefts from Jewish pawnshops and houses were not common over the pe-

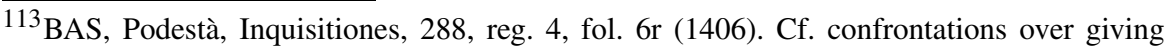
way involving peasants and slaves: ibid., 344, fol. 20r; BAS, Podestà, Vacchettini, 5, reg. for June-Sept. 1455 (Sept. 7, 1455).

${ }^{114}$ BAS, Comune, Governo, 385, Libri partitorum, reg. 5, fol. 15r.

${ }^{115}$ BAS, Comune, Governo, 310, Libri provisionum, reg. 1, fol. 19v.

${ }^{116}$ BAS, Podestà, Vacchettini, 20, reg. for 1498, fol. 71r (Aug. 13, 1498).

${ }^{117}$ Rosella Rinaldi, "Un inventario di beni dell' anno 1503: Abramo Sforno e la sua attività di prestatore," Il Carrobbio 9 (1983): 316.

${ }^{118}$ For examples at San Giovanni in Persiceto in 1471 and in Budrio in 1473, see Campanini, "Quod possit fenerari," 192-93; BAS, Podestà, Vacchettini, 10, reg. for Nov. 1472-Oct. 1473, fols. 136r-v, 140r-141r, 160v-162r, $203 \mathrm{v}$.

${ }^{119}$ BAS, Comune, Governo, 311, Libri provisionum, fol. 65r (Feb. 26, 1503).

${ }^{120}$ BAS, Podestà, Inquisitiones, 361, reg. 2, fols. 184r-188r (1456).
} 
riod as a whole, however: they accounted for only two among 250 burglaries, thefts, and robberies prosecuted between 1400 and 1419, for example, and one of those was by a Jewish convert. ${ }^{121}$ Thieves who were prosecuted for multiple thefts over an extended period rarely visited the houses and banks of Jews to steal. When Paolo di Niccolò was hanged for theft in 1450, his list of seventeen charges contained just one involving theft from a Jew's house: stealing some cheese from the house of Abram. ${ }^{122}$ The case of a vagabond, Tommaso da Benevento, hanged in 1458, was similar. ${ }^{123}$ Christian thieves left Jewish pawnshops alone, perhaps because they were more guarded or better secured than other premises or because this was where thieves disposed of their stolen goods. The thief Barnaba Fracassati found that the information and detection networks around Jewish pawnshops were too strong: news of thefts of silver and jewels spread quickly to other traders in valuable goods. ${ }^{124}$ Just as numerous, in fact, were the Jews and converts who stole from Jewish houses. In 1412, a Jew from Pesaro together with a converted Jew described as a vagabond stole clothing from Jews' houses in Bologna, and in punishment one was whipped, the other banned. ${ }^{125}$ In 1419, a French Jew resident in Bologna, Aron di Musetto, broke into the house of Musetto di Sabato da Pesaro through an adjoining wall, forced open a chest, and stole money, cloth, and armor. ${ }^{126}$ A more professional thief was the German "vagabond" Salomone di Isacco, who was charged between 1436 and 1440 with six counts of theft from Jews' houses in Treviso, Città di Castello, Feltre, and Modena, as well as from a guest at the Jews' hospice in Bologna. ${ }^{127}$ Further cases of Jews stealing valuables from houses in Bologna occurred in the 1470 s. ${ }^{128}$

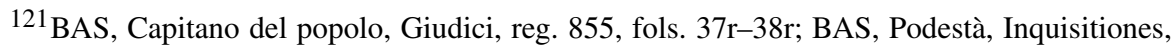
298, reg. 4, fol. 37r (1412).

${ }^{122}$ BAS, Podestà, Inquisitiones, 356, reg. 2, fols. 33r-35r.

${ }^{123}$ Out of twenty counts of theft, there was one theft from a Jew's house: that of Musetto di Angelo, from which a woman's robe and three tablecloths were stolen; BAS, Podestà, Inquisitiones, 363, fols. 116r-124r. For similar cases, see ibid., 385, reg. 2, fols. 161r (1484), 363r (1485).

${ }^{124}$ BAS, Podestà, Vacchettini, 10, reg. for $1472-73$, fol. 140r.

${ }^{125}$ BAS, Podestà, Inquisitiones, 297, reg. 3, fol. 62r (1412); ibid., 298, reg. 4, fol. 37r (1412);

Rinaldi, "Topografia documentaria," 64.

${ }^{126}$ BAS, Podestà, Inquisitiones, 311, reg. 1, fols. 78r-80r (1419).

${ }^{127}$ Salomone confessed, but further proceedings were inhibited by the bishop's vicar on account of Salomone's imminent baptism: BAS, Podestà, Inquisitiones, 347, reg. 1, fols. 41r-42r (1440).

${ }^{128}$ BAS, Podestà, Inquisitiones, 377, fols. 117r-118r (1475); ibid., 380, fol. 110r (1479, Salomone ebreo and Matteo di Battista).
} 


\section{Sexual Offenses}

The rate and types of prosecutions for sexual offenses could be a further index of integration. Historians have often focused on the sexual offenses of Jewish men with Christian women. ${ }^{129}$ It is necessary to distinguish among Jewish sexual "crimes," however: not all were committed against Christians, and prosecutions for such offenses tended to come in clusters. One of the first Bolognese prosecutions occurred in 1390, in the case against Abram di Bonaventura da Rimini for having sex with Christian women; ${ }^{130}$ but there was then no other trial of a Jew for a sex crime until 1416, when Gaio di Matasia da Sulmona was tried for having sex with a Jewish girl at Castel San Giovanni. ${ }^{131}$ Three cases occurred in the 1420s (two of sex with Christian prostitutes, one of attempted rape of a Jewish woman), and two in July 1485 (sex with Christian prostitutes). ${ }^{132}$ Between these dates, Abram di Dattilo was prosecuted for a sexual affair with the wife of a German resident in Bologna (he denied the charge, and the witnesses had only seen them talking together in the street); a Jewish man resident in Bologna confessed to having sex with another Jew while they slept in the same bed (he was acquitted); two French Jews were convicted of rape and sodomy of Jewish youths; and two Jews were sentenced first to imprisonment, then to banishment for sex with Christian women. ${ }^{133}$ To use the hermeneutic of "negative approximation," 134 the crime of Jewish sex with Christian women was thus not a normal or consistent practice. The court also punished sexual offenses against Jews. It looks as if it might in fact have been difficult for Jewish men to have sex with Christian prostitutes: Consiglio di Musetto confessed in 1456 that he had asked several Christian women for sex and had been refused; and when

\footnotetext{
${ }^{129}$ See the discussion earlier in this article of the role of sexual crimes in the historiography of Jewish communities in medieval Italy. See also Muzzarelli, "I banchieri ebrei," 125-26.

${ }^{130}$ BAS, Podestà, Inquisitiones, 258, reg. 1, fol. 71r (1390).

${ }^{131}$ BAS, Podestà, Inquisitiones, 304, reg. 2, fol. 27r (1416).

${ }^{132}$ BAS, Capitano del popolo, Giudici, reg. 862, fols. 17r-18r (1422); BAS, Podestà, Inquisitiones, 323, reg. 2, fols. 133r-135r (1426); BAS, Podestà, Inquisitiones, 386, reg. 1, fols. 273r-274r, 276r (1485); BAS, Podestà, Sententiae, 38, fol. 47v (1426).

${ }^{133}$ BAS, Podestà, Inquisitiones, 336, reg. 2, fols. 44r-48r (1433); ibid., 340, reg. 4, fol. 64r (1436); ibid., 341, reg. 1, fol. 75r (1437); ibid., 361, reg. 1, fols. 196r-198r (1456); BAS, Comune, Governo, Libri partitorum, reg. 2, fols. 111v-112r. Andrea Barbazza's consilium on the appropriate penalty for Jews fornicating with Christian women may relate to the 1456 case: Consiliorum quatuor admiranda volumina consumatissimi i.u. monarce d. Andree Barbatie siculino (Venice, 1516), IV, fols. 134v-135v (consilium 63).

134 "Negative approximation" refers to "defining normalcy from pathology." Ermanno Orlando, Migrazioni mediterranee: Migranti, minoranze e matrimoni a Venezia nel basso Medioevo (Bologna, 2014), 26.
} 
Betta from Holland agreed, her innkeeper quickly told a guest, who entered her room and pulled Consiglio off her. ${ }^{135}$

\section{Internal Cohesion}

The court records provide some insights into the internal cohesiveness of the Jewish "community" and the manner in which tensions and criminal actions could spill out into the wider urban community. In 1423, it is true, local Jews seem to have made an effort to support the precarious position of a foreign Jew: Simonello di Lazzaro had wounded Aron di Sabbadino da Fano and was sent to prison because he could not provide any guarantors; but he did submit a plea of poverty, which two Bolognese Jews endorsed, saying that he had no means of support other than begging among other Jews and visiting friends. ${ }^{136}$ Internal hatreds and enmities are evident in other cases, however: in an episode of aggression in the very synagogue; ${ }^{137}$ in the hatred expressed by Lucio di Agnolo da Fermo toward Davide di Angelo for harboring the man who had wounded him; ${ }^{138}$ in the same Lucio's attempts to blackmail people by claiming they wanted to kill him; in the cross-burning calumny of 1414 in which a Jew, an ex-Jew, and a Christian aimed to "destroy our enemies" among the Jews of Bologna; ${ }^{139}$ or in the accusation of theft among a group of three brothers, which was resolved when the accusers accepted that the "stolen" goods had simply been relocated. ${ }^{140}$ However, signs of criminal joint enterprise with other inhabitants are few: Jews were rarely accused of joint action with Christians, ${ }^{141}$ and Christians rarely appeared to support Jews in court. ${ }^{142}$ Conversely, in 1466 the council of XVI ordered that Joseph di Moyses da Pesaro not enter or stay in the house of any Christian

135 "Va che le uno zudeo che futte la Betta," said the female innkeeper. BAS, Podestà, Vacchettini, 5, reg. for Jan.-June 1456 (June 25, 1456). These details were missed in Dean, Crime and Justice in Late Medieval Italy, 146-47.

${ }^{136}$ BAS, Podestà, Inquisitiones, 318, fols. 153r-155r (1423).

${ }^{137}$ For this case of aggression with a bread knife during a religious service, see BAS, Capitano del popolo, Giudici, reg. 854, fol. 11r (1412).

${ }^{138}$ BAS, Podestà, Inquisitiones, 300, reg. 2, fol. 18r (1413).

139 “Disfare nostri nimici.” BAS, Podestà, Inquisitiones, 301, reg. 2, fols. 29r-31r (1414).

${ }^{140}$ BAS, Podestà, Inquisitiones, 377, fols. 117r-118r (1475).

${ }^{141}$ In addition to the cases of Enoch di Salomone and of the conspirators in calumny (Rinaldi, "Topografia documentaria," 64-65), there is only the case of Salomone and Matteo (n. 128 above).

${ }^{142}$ To date I have noted only two instances: in 1479, six Christian witnesses attested to the good fama of Leone di Daniele, prosecuted for theft (BAS, Podestà, Inquisitiones, 380, fols. 122r-124r), and in 1433, two Christians attested to the good fama of Manuele di Beniamino da Rimini, accused of sodomy (ibid., 336, reg. 2, fols. 44r-48r). 
in Bologna, on pain of a fine of 100 ducats. ${ }^{143}$ "Good Christians shunned Jews." 144

\section{Illegal Gambling}

One further limit to integration is suggested by judicial sources on illegal gambling. Davide di Musetto "da Abacho" twice lodged formal complaints with the criminal judge about his gambling losses: on one occasion, in February 1472, it was against a fellow Jew, Ventura di Abram, but in July of the same year it was against a dyer, Guglielmo di Matteo, who had "induced" him to play a forbidden card game ("ludum condempnatum alias dictum labasetta") and relieved him of 300 ducats. ${ }^{145}$ Davide wanted Guglielmo punished. Jews were also fined when discovered gambling by the podestà's patrolmen: when alerted by a secret denunciation that Leo di Ventura was playing "Lose and Win," a dice game, with a notary, a tailor, and a married woman, the patrol caught them in the act. ${ }^{146}$ One Jew was condemned in 1413 to a fine and ten years in exile for having, among other things, "mixed with Christians in the public gaming-house [barataria]," where he bet large sums and blasphemed. ${ }^{147}$ When Enoch di Salomone da Ferrara was interrogated in 1473 on suspicion of counterfeiting coins, he was asked what trade he had been practicing in Bologna for the past sixteen months, and he replied "the trade of playing at dice and tables, and that he had won a lot of money." Asked if he had frequented the houses of any Christians, and if so what he had done there, he gave some names and said that he had done "nothing other than play at dice and tables." 148 It is significant that, under strong suspicion of serious crime (he later confessed), Enoch believed that gambling could be a credible explanation for his presence in Christian houses. Yet it was dangerous for Jews to choose card and dice games as a mode of association with their Christian acquaintances: gambling was a leveling process in which differences of class, gender, and ethnicity were temporarily suspended by the play of fortune, ${ }^{149}$ but the disputes that arose when losers suspected bad play

\footnotetext{
${ }^{143}$ BAS, Comune, Governo, 386, Libri partitorum, reg. 6, fol. 7r.

${ }^{144}$ Stow, Alienated Minority, 235.

${ }^{145}$ BAS, Podestà, Vacchettini, 10, reg. for Nov. 1471-Oct. 1472, fol. $167 \mathrm{v}$; ibid., reg. for Nov. 1472-Oct. 1473, fol. 10r. For the game of bassetta, see Jonathan Walker, "Gambling and Venetian Noblemen c.1500-1700," Past and Present 162 (1999): 29-30.

${ }^{146}$ BAS, Podestà, Vacchettini, 3, reg. for 1424-25 (Aug. 1, 1424). Another example may be found in ibid., reg. for 1423: Dattilo playing dice with Clemente Manzolini.

${ }^{147}$ BAS, Podestà, Inquisitiones, 300, reg. 2, fol. 18r (1413).

${ }^{148}$ BAS, Podestà, Vacchettini, 10, reg. for Nov. 1472-Oct. 1473, fol. 79r.

${ }^{149}$ Walker, "Gambling and Venetian Noblemen," 30.
} 
were magnified by those very differences. ${ }^{150}$ Renaissance governments saw gambling as a potent source of conflict, blasphemy, and bloodshed. Jews were not often discovered gambling with Christians. In the records of the Bolognese Ufficio del Fango, which levied fines for all manner of minor public order offenses, from using fraudulent weights and measures to throwing dirt into the streets and carrying weapons, Jews rarely appear: in twenty-seven registers covering most of the years 1427-57, only one Jew was fined (for dirt in front of his house), whereas hundreds of Christians were fined, forty of them for gambling in one year alone. ${ }^{151}$ For Jews, the gaming house was a place to be avoided.

\section{Jews and Students Compared}

A further trace of the limits of integration can come from a contrast between trials involving foreign Jews and trials involving another subgroup in the Renaissance city: non-Bolognese students. The object here is to contrast their involvement in crime and criminal justice, not as groups in themselves. Though students did not form a separate religious or ethnic category, both they and Jews enjoyed legal protections and privileges, the former as clerics (some of them), the latter as contractors and Roman-law citizens. They both were impermanent residents. ${ }^{152}$ They both came from a broad swath of medieval Europe: Jews from other cities of Italy and from the wider diaspora (Germany, France, Spain), students from all the regions of Italy and from other parts of southern and northern Europe. In criminal trials involving students, the frequency and intensity of violence is strikingly high, even allowing for the likelihood that the full spectrum of student violence is not present in the civic court records because the university rectors probably dealt with minor cases between students. ${ }^{153}$ In a sample of sixty-seven trials held between 1350 and 1500, compiled in a discontinuous fashion from the registers covering forty-five years, the majority of cases (fifty-two) involve violence, with just a scattering of other offenses, such as coin-clipping, ${ }^{154}$ fornication,

\footnotetext{
${ }^{150}$ See the case in Simonsohn, Jews in the Duchy of Milan, 327 (1461-62).

${ }^{151}$ BAS, Podestà, Ufficio acque, strade e fango, busta 36 . The Jew, Bonaventura, appears on June 5, 1427.

${ }^{152}$ For students as an international, transitory social group, see Jacques Le Goff, "Les universités e les pouvoirs publics au Moyen Âge et à la Renaissance," in Pour un autre Moyen Âge: Temps, travail et culture en Occident (n.p., 1977), 211.

${ }^{153}$ Carlo Malagola, Statuti delle università e dei collegi dello Studio bolognese (Bologna, 1888), 243-44. Hastings Rashdall claimed that the city recognized the rectors' criminal jurisdiction over law students in 1411, but the document he referred to does not support this claim. Rashdall, The Universities of Europe in the Middle Ages (Oxford, 1936), 1:179.

${ }^{154}$ BAS, Podestà, Inquisitiones, 355, reg. 2, fol. 74r (1450); BAS, Capitano del popolo, Giudici, reg. 856 (1413). For another case in 1428, see Guido Zaccagnini, Storia dello Studio di Bologna durante il Rinascimento (Geneva, 1930), 74.
} 
or, more commonly, theft (with students more often being the victims, particularly of their servants and former servants, ${ }^{155}$ than the perpetrators). ${ }^{156}$ Cases of violence lack the asymmetry of Jewish cases, as they are evenly divided into violence inflicted and violence suffered. The civic court dealt with serious violence between students, wounds inflicted with swords and knives, in particular, ${ }^{157}$ and with fights and brawls with other elements of urban society, some of which would seem to relate to the difficulties of students' access to money and sex. ${ }^{158}$ Students were rarely murdered, however (only four cases in the sample). ${ }^{159}$ Trials of students of canon law tended to be halted by the bishop's vicar-general and claimed by the ecclesiastical court, so the eventual outcome of trials associated with their alleged sword fights in the streets is unknown. ${ }^{160}$ Student crime in the podestà's court thus had a particular pattern: the proportion of violent offenses, both committed and sustained, was high, though homicide was rare; and the proportions of other crimes - theft, robbery, and the whole gamut of sexual offenses-were low. Moreover, one feature stands out — the frequent use of swords-which is certainly not found in cases of violence involving Jews.

\section{Conclusion}

The historiography that stresses integration would point to the facts that Jews did not exhibit a reluctance to resort to the criminal courts, but rather exhibited an instrumentality in invoking urban justice against their Jewish and Christian enemies and offenders. Given the small number of cases over an extended period it cannot be said that any particular faults by Jews were seized on and penalized. Nor were Jews denied due process: cases against Jews generally followed the same procedural paths as those against other suspects. Jews did occasionally act as witnesses in criminal investigations

\footnotetext{
${ }^{155}$ BAS, Podestà, Inquisitiones, 204, reg. 8, fol. 168r (1367); ibid., 303, reg. 2, fol. 33r. Other cases: ibid., 240, reg. 2, fol. 74r (1382); ibid., 362, reg. 1, fol. 121r (1457).

${ }^{156}$ BAS, Podestà, Inquisitiones, 259, reg. 6, fol. 68r (1391); ibid., 287, reg. 3, fol. 73r (1406); ibid., 339, fol. 48r (1434).

${ }^{157}$ BAS, Podestà, Inquisitiones, 266, reg. 1, fol. 240r (1394); ibid., 305, reg. 3, fol. 61r (1416); ibid., 306, reg. 1, fols. 65r-68r (1417); ibid., 288, reg. 4, fols. 54r-59v (1406).

${ }^{158}$ BAS, Podestà, Inquisitiones, 268, reg. 2, fols. 43r-45v (1395); ibid., 272, reg. 4, fol. 123r (1397); BAS, Capitano del popolo, Giudici, reg. 856 (1413).

${ }^{159}$ BAS, Podestà, Sententiae, 37 (Sept. 1421); BAS, Podestà, Inquisitiones, 335, fol. 75r (1433); BAS, Podestà, Inquisitiones, 396, fol. 125r; BAS, Comune, Governo, Libri provisionum, reg. 1, fol. 46r.

${ }^{160}$ BAS, Podestà, Inquisitiones, 220, reg. 6, fols. 42r-43r (1374); ibid., 231, reg. 4, fols. 46r$47 \mathrm{v}(1379)$.
} 
and trials, and, equally occasionally, Christians spoke up as character witnesses for Jewish defendants. A calumny against leading Jews for alleged cross burning was exposed as such, and the culprits were convicted. An attempted blood libel was also quickly discredited. Jews can be found gambling with Christian men and women. The evidence from the criminal court might be thought to suggest coexistence more than conflict: illicit sex was rarely prosecuted, and Jews were rarely victimized by burglars and assailants. Their pawnshops were informally protected from larceny. The prosecuted sexual crimes of Jews were few, with just four fifteenth-century convictions for sex with Christian women, and in other cases the court acted to punish sexual offenses against Jews. The criminal court and its processes could therefore be said to have acted to protect Jews: unmasking antisemitic calumnies and prosecuting and punishing attacks on individual Jews.

A historiography focusing on discrimination would instead point to the fact that Jewish moneylending activities did attract occasional ransacks and some burglaries and thefts-increasingly in the later fifteenth century, in a context more critical of Jewish moneylending. Jewish fears of ransack, expressed in condotte, were realized in Bologna. Jews did attract some specific forms of violence, which can be labeled as antisemitic rather than quotidian, whether in the form of verbal attack in the street, or stoning, or sabbath-day hat-grabbing. Moreover, cases involving Jews did bear some unusual features: Jews held in jail seem to have been treated as objects for conversion or exploitation; some criminal charges were marked by heightened rhetoric and the addition of "sacrilege" as an aggravating element; in the case of some Jewish suspects, the statutory regulations on procedure, as regards prescription or torture, were not observed. Furthermore, if the indictments are accurate descriptions of acts of violence, asymmetries of behavior existed: Jews were subjected to frenzied killings, but did not inflict them; Jews were more often victims of assault than they were assailants; Jewish aggressivity was markedly restrained; Jews were rarely found with bladed weapons; and they rarely had Christian partners in crime. On balance, therefore, the evidence cannot provide unambiguous support for a history of integration.

Jonathan Elukin recently challenged the dominance of violence in the history of Jewish experience in medieval Europe, suggesting that alongside, or against, the traditional story of "alienation" and expulsion from/by the Christian majority was a different story of attachment and support. Focusing on England, France, and Germany in the thirteenth and fourteenth centuries, Elukin stresses how far Jews had become part of local societies, and how quickly integration was reestablished after episodic outbreaks of antisemitic violence: Jews turned to Christian authorities for protection and refuge; they lived safely in "isolated places"; they had continuing peaceful relations with their clients; and their experience of violence differed little from that of their 
Christian neighbors. ${ }^{161}$ Elukin's interpretation has been criticized for downplaying the number and frequency of violent attacks on Jews after the midfourteenth century and for "misplaced" optimism in seeing violent outbursts against Jews as disconnected episodes. ${ }^{162}$ These criticisms suggest that the evidence for "alienation" is stronger than Elukin allowed. On the other hand, the evidence presented in this essay suggests that the dichotomy between "alienation" and "attachment" may itself be misplaced, as both were present at different moments across the period. In a source (trial records) whose very nature should lead to expectations of conflict and persecution, the signs of these are merely sporadic - a cross-burning calumny, oppression or exploitation in prison, occasional ransacks of Jewish banks-while the signs of integration and support are also evident, if in limited ways, in the observation of due process, the informal protection of Jewish premises, and the rarity of sex offenses. It has been claimed that "in a society where violence was quotidian, foreign, marginalized, and poorer-than-average communities experienced a particularly high rate of crime."163 That this was not the case for Jews in Bologna may be ascribed to the fact that they were not all foreign, marginalized, or poor.

Over thirty years ago, Robert Bonfil attacked Cecil Roth's presentation of Christian tolerance of Jews and of Jewish participation in Italian Renaissance culture, exclaiming that "persecutions, blood libels, expulsions, the perennial precariousness of living on the terms of a condotta" were certainly more than "a small cloud in a vast blue sky."164 Bonfil's view has recently been reiterated by Stephen Bowd, as if there were an agenda still to be completed: "The hazily positive view of Renaissance Italian tolerance must ... be revised." ${ }^{65}$ But in fifteenth-century Bologna there was no persecution, no successful blood libel, and no expulsion. What the judicial records reveal instead was sporadic, persistent, but low-level discrimination, aggravation, and

${ }_{161}$ Jonathan Elukin, Living Together, Living Apart: Rethinking Jewish-Christian Relations in the Middle Ages (Princeton, NJ, 2007), 75-91.

162 “This unmitigated optimism seems misplaced." Yvonne Friedman, review of Living Together, Living Apart, by Jonathan Elukin, Journal of Ecclesiastical History 60 (2009): 560. See also the reviews of Elukin's book by David Timmer, Church History 76 (2007): 83031; Jonathan Boyarin, Speculum 83 (2008): 981-82; and Norman Roth, American Historical Review 114 (2009): 189-90.

${ }^{163}$ Alain Ducellier, Bernard Doumarc, Brünehilde Imhaus, and Jean de Miceli, Les chemins de l'exil: Bouleversements de l'Est européen et migrations vers l'Ouest à la fin du Moyen Âge (Paris, 1992), 194-95.

${ }^{164}$ Robert Bonfil, "The Historian's Perception of the Jews in the Italian Renaissance: Towards a Reappraisal," Revue des études juives 143 (1984): 70; Robert Bonfil, Jewish Life in Renaissance Italy (Berkeley, 1994), 8-10.

165 "On Everyone's Lips": Humanists, Jews and the Tale of Simon of Trent, ed. Stephen Bowd and J. Donald Cullington (Tempe, AZ, 2012), 18. 
exploitation within a context of respect for judicial due process. Is it time to revise Bonfil's revision?

Acknowledgments I would like to thank Kate Lowe, Peter Denley, and the journal's anonymous reviewers for their helpful comments on earlier versions of this article.

Open Access This article is distributed under the terms of the Creative Commons Attribution 4.0 International License (http://creativecommons.org/licenses/by/4.0/), which permits unrestricted use, distribution, and reproduction in any medium, provided you give appropriate credit to the original author(s) and the source, provide a link to the Creative Commons license, and indicate if changes were made. 